DOI https://doi.org/10.30525/978-9934-26-179-4-9

\title{
НОВА КОНСТИТУЦІЯ ЯК ЗАСІБ ВИРІШЕННЯ КОНСТИТУЦЙНОЇ КРИЗИ
}

\author{
Макаренко Я. С. \\ магістр \\ Національний університет "Одеська юридична академія» \\ м. Одеса, Украӥна
}

Нівелювання проблем формування конституційної свідомості (масової i індивідуальної), знищення механізмів органічного «запровадження « законодавства держави i юридичної практики в систему конституціоналізму, зупинення розвитку конституційних відносин, ігнорування спеціального «набору» засобів захисту конституційної законності(конституційності) створило засади необхідні для створення абсолютно нового суспільного договору.

Свої праці дослідженням історії створення, розбудови та розвитку конституціоналізму присвятили І. Бойко, В. Гончаренко, В. Срмолаєв, А. Козаченко, О. Копиленко, М. Копиленко, В. Кульчицький, О. Кресін, А. Крусян, О. Мироненко, М. Орзіх, В. Рум’янцев, В. Тацій, Б. Тищик, Ю. Тодика, І. Усенко, В. Чехович, Ю. Шемшученко, інші.

Нормативно-правовою основою системи конституціоналізму виступає конституція, оскільки наділена такими усталеними юридичними характеристиками як вища юридична сила, наявність норм прямої дії, підвищена стабільність, особливий порядок прийняття та внесення змін.

Відзначення у 2021 році 30 незалежності України, зобов'язання, взяті на себе Україною актуалізували питання щодо необхідності публічних дискусій та наукових пошуків, щодо розробки та прийняття нового установчого акту держави.

До зміни тексту Основного Закону країни підштовхує також наступне. Конституція в редакції 1996 року була продуктом компромісу посткомуністичної та націонал-демократичної еліт, а й відтак вже більше не відповідає на запит часу та суспільства. Проведення структурних, а насправді косметичних реформ гальмує розвиток держави, вносить дисбаланс у роботу існуючих державних органів, а створення нових органів, не передбачених Конституцією, взагалі перетворює країну на великий бюрократичний механізм. Внесення парламентарями правок до Конституції лише погіршує ситуацію, у зв'язку відсутністю розуміння структурного механізму тексту Конституції й законодавства в цілому. 
Визначені Конституцією України «стовпи» побудови суспільства були зруйновані, в погоні за власною значимістю відбулась зміна орієнтирів державних установ.

Президент Томас Джефферсон, один 3 батьків-засновників Конституції США, зазначав, що «Не просить у Бога того, що може дати Конституція».

Зокрема, у правовій державі в розпалі політичної боротьби орган конституційної юрисдикції має забезпечити безумовність правил гри та ухвалити таке рішення, яке гарантуватиме пріоритет законності над політичною доцільністю. Однак в Україні все йде по зовсім іншому сценарію.

18 жовтня 1996 розпочав роботу Конституційний Суд України, в основу створення якого було покладено столітні напрацювання в сфері конституційного судочинства в країнах Західної Європи. Проте за його існування в країні відбулося декілька визначальних конституційних криз, форма державного правління в Україні змінювалась тричі.

Так у справі № 1-46/2003 КСУ вирішив, що виконання обов'язків Президента України Л. Кучмою за час дії Конституції 1996 до 14 листопада 1999 не може вважатися 5-річним строком повноважень Президента України, а право бути обраним на посаду Президента України після прийняття Конституції України 1996 р. виникло один раз і було реалізоване у 1999 році [2].

Саме тоді деякі судді в окремій думці заперечували можливість балотуватися на чергових виборах 2004 року тодішнього Президента, оскільки вважали юридично хибним твердження, що обрання Президентом відбулося саме «за чинною Конституцією України».

Після цього у 2008 році Конституційний Суд ухвалив рішення у справі № 1-40/2008 про неможливість участі окремих депутатів у створенні коаліції. Лише в лютому 2010 року, після набрання чинності Закону про Регламент Верховної Ради України система коаліції депутатських фракцій набула завершеності, оскільки законодавець чітко виписав процедуру формування і діяльності коаліційної більшості [3].

Наступним критичним стало рішення у справі № 1-45/2010, відповідно до якого Конституційний Суд вирішив, що Закон України «Про внесення змін до Конституції України» від 8 грудня 2004 № 2222IV не відповідає Конституції у зв'язку з порушенням конституційної процедури його розгляду та прийняття [4]. А відтак, Україна знову стала президентсько-парламентською республікою.

3 часом конституційна криза становилася лише глибше та досягла свого пику у 2019 році, коли КСУ у справі № 1-152/2019 (3426/19), визнав таким, що «відповідає вимогам частини другої статті 5 
Конституції України» указ Президента України від 21 липня 2019 року про достроковий розпуск Верховної Ради [5].

Крім того, вплив на суддів КСУ з боку політиків та олігархічних груп, завдав непоправимої шкоди легітимності КСУ, що втілилась у низці дуже дискусійних рішень, у тому числі в рішенні № 124/2020(393/20) від 27 жовтня 2020 щодо скасування значної частини антикорупційної реформи через власні інтереси [6]. Зокрема КСУ закрив публічний реєстр декларацій, скасував кримінальну відповідальність за внесення неправдивих відомостей в деклараціях, а дисциплінарна та адміністративна відповідальність стали неможливими для практичного застосування. Відтак через визнання Конституційним судом неконституційними норм щодо недостовірного декларування та повноважень НАЗК Україна ризикувала втратити підтримку МВФ, Світового банку, інших міжнародних партнерів, призвело до вуличних протестів та ще більшого порушення конституційних норм, коли Президент вніс до парламенту законопроект, яким запропонував у позаконституційний спосіб повністю оновити складу КСУ та визнати його скандальне рішення «нікчемним». У правовій державі, де поважається принцип верховенства права, реагування на факти порушення прав людини безпосередньо шляхом видання указів $\epsilon$ сумнівним стосовно його легітимності $[9$, с. 86].

Відтак заклики різних політичних сил щодо заключення нового суспільного договору не мали підгрунтя, й носили лише популістичний характер, отримали міцну основу та реальний привід для пошуку та визначення шляхів, методів, засобів створення та захисту Конституції, що $\epsilon$ особливо важливим для країн, орієнтованих на створення демократичної правової держави з безумовним визнанням верховенства права та вищої юридичної сили Конституції.

\section{Література:}

1. Конституція України: Закон України від 28 червня 1996 р. № 254к/96-ВР / Верховна Рада України. Відомості Верховної Ради України. 1996. № 30. URL: https://zakon.rada.gov.ua.

2. Рішення КСУ у справі № 1-46/2003 (№ 22-рп/2003) щодо строків перебування на посту Президента України. URL: https://zakon.rada.gov.ua/laws/show/v022p710-03\#Text.

3. Рішення КСУ у справі № 1-40/2008 (№ 1-рп/2008) про коаліцію депутатських фракцій у Верховній Раді України. URL: https://zakon.rada.gov.ua/laws/show/v016p710-08\#Text. 
4. Рішення КСУ у справі № 1-45/2010 (№ 20-рп/2010) про додержання процедури внесення змін до Конституції України. URL: https://zakon.rada.gov.ua/laws/show/v020p710-10\#Text.

5. Рішення КСУ у справі № 1-152/2019(3426/19) (№ 6-p/2019) щодо відповідності Конституції України (конституційності) Указу Президента України «Про дострокове припинення повноважень Верховної Ради України та призначення позачергових виборів». URL: https://zakon.rada.gov.ua/laws/show/v006p710-19\#Text.

6. Рішення КСУ у справі № 1-24/2020(393/20) (№ 13-p/2020) щодо відповідності Конституції України (конституційності) окремих положень Закону України «Про запобігання корупції», Кримінального кодексу України. URL: https://zakon.rada.gov.ua/laws/show/v013p710-20\#Text.

7. Проект Закону про конституційну процедуру № 4533 від 21.12.2020. URL: http://w1.c1.rada.gov.ua/pls/zweb2/webproc4_1?pf3511= 70729 .

8. Проект Закону про процедуру розгляду справ і виконання рішень Конституційного Суду України № 4533-1 від 06.01.2021. URL: http://w1.c1.rada.gov.ua/pls/zweb2/webproc4_1?pf3511=70801.

9. Конституційна конфліктологія (конституційні механізми подолання політичних криз) : посібник / Г.М. Волянська, М.В. Оніщук, M.В. Савчин та ін. К. : Ін-т громадян. сусп-ва, 2008. 188 с. URL: https://www.csi.org.ua/wp-content/uploads/2008/03/konflikt-c-c-c.pdf.

\title{
DOI https://doi.org/10.30525/978-9934-26-179-4-10
}

\section{ПРАКТИЧНІ АСПЕКТИ РЕАЛІЗАЦІЇ ПРИНЦИПУ ЗАКОННОСТІ ЩОДО ДИСЦИПЛІНАРНОЇ ВІДПОВІДАЛЬНОСТІ СУДДІ}

\author{
Малашенкова Т. М. \\ аспірант відділу проблеми кримінального права, \\ кримінологї та судоустрою \\ Інститут держави і права імені В. М. Корецького \\ Начіональної академії наук України \\ м. Київ, Україна
}

Україна з 2010 року формує власну модель дисциплінарної відповідальності суддів, про що свідчить низка судових реформ. Зокрема, ВР України ухвалено зміни до Конституції України щодо 